1

\title{
Chronic Benzene Exposure Aggravates Pressure Overload-Induced Cardiac Dysfunction
}

Igor N. Zelko ${ }^{1-4}$, Sujith Dassanayaka ${ }^{2,4}$, Marina V. Malovichko ${ }^{1-4}$, Caitlin M. Howard ${ }^{2-4}$, Lauren

F. Garrett ${ }^{2-4}$, Uchida Shizuka ${ }^{1-3}$, Kenneth R. Brittian ${ }^{2-4}$, Daniel J. Conklin ${ }^{1-4}$, Steven P. Jones ${ }^{2-4}$ and Sanjay Srivastava ${ }^{1-4}$

${ }^{1}$ University of Louisville Superfund Research Center, ${ }^{2}$ Diabetes and Obesity Center, ${ }^{3}$ Envirome Institute, and ${ }^{4}$ Department of Medicine, Division of Environmental Medicine, University of Louisville, Louisville, KY 40202

Running Title: Benzene-induced cardiac dysfunction

Conflict of interest statement: The authors have declared that no conflict of interest exists

Address correspondence to: $\quad$ Igor N. Zelko, $\mathrm{PhD}$

Department of Medicine

Division of Environmental Medicine

Room 310 CII Building

302 E. Muhammad Ali Blvd

Louisville, KY 40202

Phone: 502-852-9064

E-mail: igor.zelko@louisville.edu

or

Sanjay Srivastava, $\mathrm{PhD}$

Superfund Research Center,

Room 306 CII Building

302 E. Muhammad Ali Blvd

Louisville, KY 40202

Phone: 502-852-5724; Fax: 502-852-5834

E-mail: sanjay@,louisville.edu 


\section{ABSTRACT}

37 Benzene is a ubiquitous environmental pollutant abundant in household products, petrochemicals and cigarette smoke. Benzene is a well-known carcinogen in humans and experimental animals; however, little is known about the cardiovascular toxicity of benzene. Recent population-based studies indicate that benzene exposure is associated with an increased risk for heart failure.

41 Nonetheless, it is unclear whether benzene exposure is sufficient to induce and/or exacerbate heart

42 failure. We examined the effects of benzene (50 ppm, 6 h/day, 5 days/week, 6 weeks) or HEPA-

43 filtered air exposure on transverse aortic constriction (TAC)-induced pressure overload in male

44 C57BL/6J mice. Our data show that benzene exposure had no effect on cardiac function in the Sham group; however, it significantly compromised cardiac function as depicted by a significant decrease in fractional shortening and ejection fraction, as compared with TAC/Air-exposed mice. RNA-seq analysis of the cardiac tissue from the TAC/benzene-exposed mice showed a significant increase in several genes associated with adhesion molecules, cell-cell adhesion, inflammation, and stress response. In particular, neutrophils were implicated in our unbiased analyses. Indeed, immunofluorescence studies showed that TAC/benzene exposure promotes infiltration of $\mathrm{CD}_{11 \mathrm{~b}^{+} / \mathrm{S} 100 \mathrm{~A}^{+} / \text {myeloperoxidase }}{ }^{+}$-positive neutrophils in the hearts by 3 -fold. In vitro, the benzene metabolites, hydroquinone and catechol, induced the expression of P-selectin in cardiac microvascular endothelial cells by 5-fold and increased the adhesion of neutrophils to these endothelial cells by 1.5-2.0-fold. Benzene metabolite-induced adhesion of neutrophils to the endothelial cells was attenuated by anti-P-selectin antibody. Together, these data suggest that benzene exacerbates heart failure by promoting endothelial activation and neutrophil recruitment. 


\section{Introduction}

Environmental pollution is a health problem worldwide. More than 9 million premature deaths are attributed to pollution every year, out of which 6 million deaths are related to air pollution (1).

64 Nearly half of the air pollution-associated deaths are ascribed to cardiovascular disease (1). Cardiovascular health effects of criteria pollutants (particulate matter 2.5 , sulfur dioxide, carbon monoxide, nitrogen oxides, ozone and lead) have been extensively studied in the last three decades;

67 however, information about the potential cardiovascular toxicity of other airborne chemicals, such as volatile organic compounds (e.g. benzene, 1,3-butadiene, vinyl chloride, trichloroethylene etc.), is sparse. Benzene, a well-known carcinogen, is abundant in household products, cigarette smoke and automobile exhaust (2-5), and the atmospheric concentration of benzene can exceed $50 \mathrm{ppm}$, especially near the emission source. People working at gasoline pumping stations or living near hazardous waste sites can be exposed to high levels of benzene. The United States Occupational Safety and Health Administration has set the occupational benzene exposure limit of 1 ppm (6); however, occupational benzene exposure in excess of $100 \mathrm{ppm}$ has been reported in developing countries (7).

Like pollution, heart failure is a pervasive health problem. Heart failure affects more than 6.5 million people in the United States (8) and 26 million people worldwide (9). The lifetime risk for heart failure at 40 years of age is estimated to be 1 in 5 people (10). The pathogenesis of heart failure is also not clearly understood, although a substantial body of literature points to the important role of infiltrating immune cells in the development of left ventricular hypertrophy and cardiac dysfunction (11-18). Therefore, the current focus in finding new therapeutic approaches to delay advanced heart failure includes understanding the molecular mechanisms that govern cardiomyocyte interactions with immune cells (19-21). The innate immune response induced by heart failure initiates the cardiac repair process, and involves infiltration of peripheral neutrophils (22-24).

Recent population based studies have reported that benzene exposure is associated with an increased risk for heart failure (25), and presence of mono-nitrogen oxide and benzene in the air of hospital wards is associated with a higher risk of heart failure morbidity (26). Other studies have 
benzene exposure on heart failure in well-controlled animal studies have not been studied. Here, we examined the effect of chronic benzene exposure on transverse aortic constriction (TAC)induced cardiac function and associated immune response in mice.

MATERIALS AND METHODS

Reagents: Benzene permeation tubes were obtained from Kin-Tek (La Marque, TX). Primers and probes for real-time PCR were purchased from Integrated DNA Technologies (Coralville, IA) and ThermoFisher Scientific (Waltham, MA). Sources of antibodies used for immunohistochemistry and functional studies were: anti-CD11b, myeloperoxidase (Abcam); anti-S100A8 (63N13G5)FITC from Novus (Novus, Centennial, CO); anti-CD90/Thy1 from Sino Biological (Sino Biological); CD62P from Biolegend (San Diego, CA). Murine cardiac microvascular endothelial cells (CMVEC) were obtained from CellBiologics, Chicago, IL. All other chemicals and enzymes were from Sigma Chemical Co. (St. Louis, MO), or Invitrogen (Carlsbad, CA).

Animal housing and maintenance: C57BL/6J male mice obtained from Jackson Laboratory (Bar Harbor, ME) were maintained on normal chow in a pathogen-free facility accredited by the Association for Assessment and Accreditation of Laboratory Animal Care. All procedures were approved by the University of Louisville Institutional Animal Care and Use Committee.

Animal Surgeries: For TAC (29), male C57BL/6J mice 12 weeks of age were anesthetized (intraperitoneal injections of $50 \mathrm{mg} / \mathrm{kg}$ sodium pentobarbital and $50 \mathrm{mg} / \mathrm{kg} \mathrm{ketamine}$ hydrochloride), antiseptically prepared for surgery, orally intubated, and ventilated (oxygen supplement to the room-air inlet) with a mouse ventilator (Hugo Sachs). Core body temperature was maintained at $36.5-37.5^{\circ} \mathrm{C}$ with an automatic, electronically regulated heat lamp. The aorta was visualized following an intercostal incision. A 7-0 nylon suture was looped around the aorta 116 between the brachiocephalic and left common carotid arteries. The suture was tied around a 27117 gauge needle placed adjacent to the aorta to constrict the aorta to a reproducible diameter. The needle was removed, and the chest was closed in layers. Mice were extubated upon recovery of spontaneous breathing. Analgesia (ketoprofen, $5 \mathrm{mg} / \mathrm{kg}$ ) was provided prior to recovery and by 24 
and $48 \mathrm{~h}$ post-surgery. Sham mice were subjected to the same procedure as the TAC cohort except the suture was not tied.

Benzene Exposure: One week after the TAC, mice were exposed to benzene for 6 weeks in bedding-free cages as described before (30). Briefly, benzene atmospheres were generated from liquid benzene (Sigma-Aldrich) in a KIN-TEK Analytical, Inc permeation tube. A carrier gas $\left(\mathrm{N}_{2}\right)$ was delivered to the permeation tube at $100 \mathrm{ml} / \mathrm{min}$ and diluted with HEPA- and charcoal-filtered room air (3 L/min) and diluted gas directed to an exposure unit. Flow was distributed through a fine mesh screen of a custom cyclone-type top (Teague Enterprises) that distributed air within 10\% of the mean concentration at six locations in the cage. Throughout the exposure, benzene concentrations were continuously monitored using an in-line photoionization detector (ppb RAE: Rae Industries) upstream of the exposure unit. Mice were exposed to $50 \mathrm{ppm}$ benzene (6 h/day, 5 days/week) for 6 weeks. Mice exposed to HEPA- and charcoal-filtered room air only were used as controls.

Echocardiography: At the end of the benzene exposure protocol, mice were anesthetized with $2 \%$ isoflurane, and echocardiography was performed (VisualSonics Vevo 3100), similar to our previous reports $(29,31)$. At the end of the experiment, hearts were excised for biochemical and pathological analyses. For mice in the TAC arm of the study, Doppler verification of the stenosis was used. The sonographer was blinded to the specific experimental group.

RNA Isolation and RNAseq analysis: Total RNA was extracted from the hearts of mice using TRIzol kit (Thermo Fisher Scientific, MA, USA), and the purity of RNA was analyzed using NanoDrop One (ThermoScientific, MA, USA). RNA quality was measured by Agilent 2100 bioanalyzer (Thermo Fisher Scientific, MA, USA) and samples with high RNA integrity were used for subsequent RNAseq analysis. RNA samples were processed by Novogene using mRNA and small RNA sequencing services (Novogene, Beijing, China). The resultant raw reads of the FASTQ files were processed and quality metrics were visualized using FastQC v 0.11.9. The mRNA differentially regulated genes (DEG) and pathway enrichment analysis were performed using the NGS Data Analysis pipeline (32). 
151 Histopathology: Formalin-fixed, paraffin-embedded hearts from Sham and TAC mice were

152 sectioned at $4 \mu \mathrm{m}$ thickness, and later deparaffinized, and rehydrated according to the appropriate

153 staining method. The histological staining was performed as previously described $(33,34)$. Picro-

154 Sirius Red staining was used to evaluate tissue fibrosis and general histology, and Alexa Fluor

155 555-conjugated wheat-germ agglutinin (Invitrogen) staining was used to determine the average

156 myocyte area. All images were captured at 20X magnification using the Keyence BZ-X810, all in

157 one fluorescent microscope. Both fibrosis and myocyte area were analyzed using the hybrid cell

158 count feature (BZ-H4C) associated with the Keyence system. Fibrosis was expressed as a

159 percentage of scar tissue divided by the total area of tissue.

Immunofluorescence: For immunostaining, deparaffinized and rehydrated sections were incubated for $20 \mathrm{~min}$ with $10 \mathrm{mmol} / \mathrm{L}$ citric acid $\mathrm{pH} 6.0$ (pH 9.0 for MPO staining). Nonspecific binding was blocked with 5\% normal goat serum and 0.05\% saponin (Sigma) in PBS (pH 7.4) for $30 \mathrm{~min}$. Sections were blocked and then incubated with the appropriate primary antibody in PBS with $1 \% \mathrm{BSA}$ and $0.05 \%$ saponin for $1 \mathrm{~h}$ at $37^{\circ} \mathrm{C}$ against: CD11b (Abcam), S100A8-FITC (Novus), myeloperoxidase (Abcam). Tissue sections were then incubated for $30 \mathrm{~min}$ at room temperature with respective secondary antibodies conjugated with Alexa 488, 555, or 647 (Invitrogen), and counterstained with DAPI to label nuclei. Images were made with a 20x and 60x objective.

Neutrophils isolation: Neutrophils were isolated from bone marrow as described previously (35). marrow cells were flushed from the femur and tibia and filtered through a $70 \mu \mathrm{m}$ mesh filter. For a negative selection of neutrophils, we used a Neutrophil Isolation kit from Miltenyi, Auburn, CA.

177 Neutrophil purity was always higher than 93\%.

179 Cell adhesion assay: Neutrophil adhesion to CMVEC was determined as previously described 180 (36). Briefly, CMVEC (passage 6 to 10) were seeded into 96-well plate at 25,000 cells per well in $181100 \mu \mathrm{l}$ of growth media. Twenty-four hours later confluent monolayer of endothelial cells was 
exposed to benzene metabolite catechol $(5 \mu \mathrm{M})$ for 24 hours. Cells treated with TNF $\alpha(100 \mathrm{ng} / \mathrm{mL})$ for 4 hours served as positive controls. Isolated neutrophils labeled with calcein (36) were added to endothelial cells and incubated for $30 \mathrm{~min}$ at $37^{\circ} \mathrm{C}$. Cells were rinsed with PBS containing $\mathrm{Mg}^{2+}$ and $\mathrm{Ca}^{2+}$ and the fluorescence was measured with a Synergy H1 (Biotek) fluorescence plate reader (excitation wavelength, $485 \mathrm{~nm}$ and emission wavelength, $520 \mathrm{~nm}$ ). To measure the effect of $\mathrm{p}$ selectin blocking on neutrophil adhesion, CMVEC were incubated with anti-CD62P antibodies $(25 \mu \mathrm{g} / \mathrm{mL})$ for $30 \mathrm{~min}$ prior to the neutrophil adhesion assay. For each assay, 10-12 wells were used.

Statistical Analyses: Data are presented as means \pm SEM. The statistical significance of differences was determined by t-test. A one-way analysis of variance (ANOVA) with Holm-Sidak post hoc test was used to compare differences between multiple treatment groups. P-value of $<0.05$ indicated statistically significant differences. All analyses were performed using Excel and GraphPad Prism software (GraphPad Software, San Diego, CA). Statistical analyses for echobased parameters were performed after adjustment for body weight and heart rate by two-way ANOVA with Tukey-Kramer corrections.

\section{RESULTS}

Benzene exposure exacerbates pressure overload-induced cardiac dysfunction: As expected, mice in the TAC/Air group developed significant left ventricular dilation as indicated by a significant increase in end diastolic volume (EDV), end systolic volume (ESV) and left ventricular internal diameter in diastole (LVIDd), and diameter in systole (LVIDs), and consequent decrease in fractional shortening (FS) and ejection fraction (EF), as compared with the mice in corresponding Sham/Air (Fig. 1). TAC also increased the heart mass, cardiac myocyte size and fibrosis in the heart (Fig. 1). This was accompanied with a significant increase in the fluid accumulation in the lung (Supplemental Fig. 1). Benzene exposure had no effect on myocyte size and cardiac function in the Sham group; however, it significantly compromised cardiac function as depicted by a significant increase in EDV, ESV, LVIDd, and LVIDs and resultant decrease in FS and EF, as compared with TAC/Air-exposed mice (Fig. 1 and Supplemental Table 1). The other cardiac function parameters such as left ventricular anterior wall thickness at diastole or systole (LVAWd and LVAWs) and left ventricular posterior wall thickness at diastole or systole 
213 (LVPWd and LVPWs), isovolumic relaxation time (IVRT), Stroke Volume (SV), and Cardiac 214 Output (CO) did not significantly change in TAC/Benzene vs TAC/Air groups (Supplemental

215 Table 1). Cardiac myocyte size and fibrosis in TAC/Benzene-exposed mice were also comparable 216 with the TAC/Air-exposed mice. Collectively, these data suggest that a 6 -week benzene exposure 217 exacerbates TAC-induced cardiac dysfunction but does not induce cardiac remodeling in Sham mice.

RNA-Seq analyses of TAC-benzene-exposed hearts: To examine the molecular mechanisms by which benzene worsens cardiac function following TAC, we performed deep RNA sequencing on the left ventricle and septum tissues. For these analyses, we used FDR $\leq 0.01$ and $0.5 \leq \log 2$ (fold change) $\leq-0.5$ to examine the differential expression of the genes. As shown in Fig $2 \mathbf{A}$, TAC upregulated 671 genes (e.g., genes involved in extracellular matrix organization and collagen formation) and downregulated 351 genes (e.g., genes involved in muscle contraction and cardiac conduction) in the air-exposed mice (see Supplemental Table 1). Exposure to benzene in Shamoperated mice did not induce any genes while uteroglobin (Scgblal) and surfactant protein $\mathrm{C}$ $(S f t p c)$ were downregulated by 8.9- and 6.1-fold. However, benzene exposure in TAC mice significantly upregulated 876 genes and downregulated 674 genes as compared with the corresponding Sham-operated controls. Comparison of the gene expression between TAC/Benzene versus TAC/Air mice showed upregulation of 50 and downregulation of 69 genes. Fig. 2B illustrates the heat-map of top the 15 upregulated and 10 downregulated genes between these groups as well as the differential expression of these genes in the other experimental groups.

234 Gene ontology of biological process and molecular function enrichment analyses of differentially expressed genes in the benzene-exposed TAC hearts show significant enrichment of the genes associated with the regulation of "neutrophil degranulation", "signaling by interleukins", "extracellular matrix organization", "platelet degranulation”, and heat shock factor-1 (HSF-1) dependent transactivation etc. (Fig. 3A). Fig. 3B shows the induction of some representative genes of these processes, and Fig. 3C displays the gene-concept network of select differentially expressed genes associated with the indicated biological pathways including neutrophil degranulation, interleukin signaling, and HSF-1 activation. 

suggest that benzene exposure affects inflammatory response and neutrophil degranulation processes in TAC hearts, we examined the abundance of inflammatory cells in the TAC/benzeneexposed hearts. As shown in Fig. 4A, benzene exposure induced massive infiltration of S100A8positive granulocytes in the hearts of TAC mice. These cells also co-stained with the pan-myeloid marker CD11b and myeloperoxidase, mostly expressed on neutrophils (Fig. 4A and 4B). Quantitative analysis shows $>3$-fold increase in S100A8 ${ }^{+}$granulocytes, $\mathrm{CD} 11 \mathrm{~b}^{+}$myeloid cells and myeloperoxidase $^{+}$neutrophils in TAC/Benzene vs TAC/Air groups (Fig. 4C). The S100A8 staining did not co-localize with the markers of $\mathrm{CD} 68^{+}$macrophages and Thy $1^{+}$fibroblasts in TAC-Benzene hearts (Supplementa1 Fig. 2). To examine the mechanisms by which benzene exposure augments neutrophil infiltration in TAC-instrumented hearts, we analyzed the RNA-seq data for the differential expression of adhesion molecules. As shown in Fig. 4D, benzene exposure did not affect the levels of adhesion molecules in the Sham-operated hearts, however, it significantly increased the transcription of Intracellular adhesion molecule-1 (Icam1), endothelialselectin (Sele), and platelet-selectin (Selp) genes in the TAC-instrumented hearts. Expression of vascular cell adhesion molecule (Vcaml) in TAC-benzene hearts was comparable with the TAC/Air hearts. Together, these data indicate that chronic benzene exposure enhances the infiltration of neutrophils, possibly by activating adhesion molecules in the myocardial endothelial cells during pressure overload-induced cardiac dysfunction.

P-Selectin facilitates the adhesion of neutrophils adhesion to the cardiac microvascular endothelial cells: Complimentary in vitro experiments with CMVEC showed that benzene metabolites hydroquinone $(5 \mu \mathrm{M}, 24 \mathrm{~h})$ and catechol $(5 \mu \mathrm{M}, 24 \mathrm{~h})$ increased the transcription of P-selectin by 5-fold (Fig. 5A) and abundance of P-selectin protein by 1.5-2-fold (Fig. 5B). Incubation of CMVEC with catechol for $24 \mathrm{~h}$ augmented the adhesion of bone marrow-derived neutrophils to CMVEC (Fig. 5C), which was attenuated by pre-incubation of CMVEC with anti-

269 P-selectin antibody (Fig. 5D). Hydroquinone and catechol also increased the expression of interleukin-8 (IL8, Supplemental Fig. 3), which can function both as a membrane-bound and

271 soluble activator of neutrophil $\beta_{2}$ integrin-mediated adhesion. Together, these observations suggest 272 that benzene-induced neutrophil infiltration in the TAC hearts could be facilitated, at least in part, 273 by the metabolic conversion of benzene to its active metabolites- hydroquinone and catechol. 


\section{DISCUSSION}

275

The major finding of this study is that chronic benzene exposure exacerbates pressure overload-

277 induced cardiac dysfunction. The TAC/Benzene-induced cardiac dysfunction is accompanied by endothelial activation and enhanced recruitment of granulocytes in the heart and differential regulation of genes involved in neutrophil degranulation, inflammatory signaling, and stress response. These studies corroborate recent reports that occupational and environmental exposure to benzene is associated with an increased risk for heart failure (25).

Inflammatory processes have long been implicated in the manifestation, progression, and consequences of ischemic heart disease $(37,38)$ and pressure- or volume overload-induced mechanical stress $(17,39-41)$. Pressure overload induces the expression of ICAMI (42) and consequent increase in the recruitment of neutrophils in the heart (39) and subsequent monocyte infiltration $(17,39)$. It diminishes TAC-induced cardiac hypertrophy and inflammation and sustains cardiac function (39), suggesting that neutrophils play a pivotal role in the manifestation of heart disease, especially heart failure. In mice, increased recruitment of S100A9 positive granulocytes, which co-stained with myeloperoxidase, suggests that TAC/Benzene exposure facilitates the infiltration of neutrophils into the hearts.

291 This is further supported by RNAseq data of cardiac tissue, demonstrating robust induction in the neutrophil specific $S 100 A 8 / A 9$, Mmp8, Lcn2, and CXcr2 transcripts. S100A8/A9 is a member of alarmins or damage-associated molecular patterns (DAMPs) that are released by the failing heart (43-45) and subsequently activate resident macrophages, fibroblasts, and endothelial cells to secrete proinflammatory cytokines and adhesion molecules (46) and augment inflammation in the cardiac tissue $(21,23,47)$. Systemic administration of S100A8/A9 facilitates the mobilization of neutrophils from the bone marrow (48) while local administration of S100A8/A9 leads to rapid recruitment of monocytes and neutrophils into the site of injury (49). Patients with myocardial infarction and elevated S100A8/A9 levels have poorer prognosis (50, 51). Overall, increased neutrophil infiltration in the hearts could play a pivotal role in benzene exposure-induced cardiac dysfunction in the pressure overload hearts. cardiac dysfunction remain unknown, it is plausible that the observed enlargement of left ventricle 
dimensions in the hearts of TAC/Benzene mice could, at least in part, be due to the induction of neutrophil gelatinase-associated lipocalin (NGAL or Lcn2) whose expression is regulated by the S100A8/A9 complex (52). Lcn2 plays a central role in the ontogeny of cardiac hypertrophy and heart failure (53-55) and can bind Mmp9 to create a complex to stabilize Mmp9 protein and enhance metalloproteinase activity with its pro-angiogenic and pro-invasive properties $(56,57)$. Moreover, S100A8/A9 can diminish cardiac myocyte contractility, resulting in attenuated cardiac ejection fraction (58). Patients of chronic heart failure have elevated plasma myeloperoxidase levels (59), and pharmacological inhibition of myeloperoxidase diminishes leukocyte recruitment, and improves ejection fraction, end diastolic/systolic volume, and left ventricular hypertrophy following myocardial infarction (60). Therefore, it is conceivable that the augmented neutrophil infiltration with subsequent release of MPO and S100A8/A9 heterodimer from activated granulocytes might affect myocyte contractility and compromise cardiac function in TAC/Benzene mice.

Increased inflammation in the hearts of mice subjected to pressure overload followed by benzene exposure is further underscored by the increased transcription of chemokines, cytokines, and their receptors (e.g. Il1 $\beta, \mathrm{Cxcl1}$, and Cxcr2). Chemokines such as CXCL1 chemokine are well known to facilitate neutrophil migration into inflamed tissues $(61)$, promote angiogenesis $(62,63)$ and regulate the recruitment of neutrophils and monocytes during cardiac remodeling and inflammation (64). Although the cellular sources (e.g., endothelial cells, granulocytes) of CXCL1 and other chemokines and cytokines in the hearts of TAC/benzene-exposed mice remain unknown, they likely augment neutrophil recruitment and migration. Benzene metabolites have been shown to increase the expression of cytokines and chemokines in the peripheral blood mononuclear cells (65) and endothelial cells (66). Our in vitro studies show that in murine cardiac microvascular endothelial cells, benzene metabolites hydroquinone and catechol increase the transcription of chemokine IL-8, which is known to bind to CXCR2 on neutrophils and trigger a signaling cascade that facilitates a firm monocyte adhesion with subsequent intravasation (67). Further studies are required to delineate the sources of chemokines and cytokines and the molecular mechanisms by which these molecules promote inflammatory signaling in the hearts of TAC/Benzene mice. Induction of heat shock proteins (HSPs) such as Hspala and Hspalb in Sham/Benzene hearts appears to be an adaptive response to circumvent inflammatory signaling. Induction of HSPs in response to chemical and mechanical stress enhances protein folding, inhibits inflammation and 
apoptosis, and provides cytoskeletal protection (68). While little is known about the role of HSPs in pressure overload-induced heart failure, heat shock factor 1 (HSF-1), the transcription factor that regulates HSPs is induced by TAC in rats and mice, and constitutive activation of HSF-1 ameliorates TAC-induced cardiac hypertrophy, fibrosis and cardiac dysfunction (69-71). Conversely, inhibition of HSF-1 impairs cardiac function in the pressure overload subjected hearts $(69,70)$. The HSF-1-mediated cardiac adaptation from pressure overload has been attributed, at least in part, to myocardial angiogenesis via suppression of p53 and subsequent induction of HSF1 (72). HSF-1 can also improve endothelial function (73) and prevent inflammatory signaling (74). Although the contribution of the HSF-1/HSP axis in the etiology of cardiac dysfunction following TAC/Benzene exposure is unclear, it is likely that these pathways are activated to prevent benzeneinduced endothelial activation. Further studies are required to examine the molecular mechanisms by which HSF-1-dependent transactivation prevents endothelial activation.

Collectively, our studies demonstrate that benzene exposure worsens pressure overload-induced cardiac dysfunction, which is accompanied by increased influx of neutrophils, alterations in cellcell adhesion, and induction of genes associated with inflammation and stress response. These studies establish the plausibility that benzene exposure is sufficient to exacerbate TAC-induced cardiac dysfunction and provide insight about the underlying mechanisms.

Acknowledgment: This study was supported in parts by NIH grants P42 ES023716, R01 HL149351, R01 HL137229, R01 HL146134, R01 HL156362, R01 HL138992, R01 HL122676, R21 ES033323, U54 HL120163, P30 GM127607, NIH S10 OD025178, and the Jewish Heritage Foundation grant OGMN190574L. 
FIGURE LEGENDS:

Figure 1. Effect of benzene exposure on left ventricle function and cardiac remodeling after pressure overload. A. Benzene exposure protocol: Transverse aortic constriction or Sham operated male C57BL/6 mice were exposed to benzene (50 ppm, 6 h/day, 5 days/week) or HEPA-filtered air (Air) for 6 weeks. At the end of the exposure protocol, echocardiography was used to measure ejection fraction (B), fractional shortening (C), end-diastolic volume (EDV; D), end-systolic volume (ESV; E), left ventricular internal diameter end diastole (LVIDd; F) and end systole (LVIDs; G). Heart weight:tibial length (TL) are presented in panel H. Panel I shows the representative images of Sirius Red-stained mid-ventricular histological sections from mouse hearts with quantitative analysis of fibrosis expressed as percent of fibrous area to total area ratio. Representative images of wheat germ agglutinin (WGA)-stained mid-ventricular histological sections from mouse hearts with quantitative analysis of myocyte area are illustrated in panel $\mathbf{J}$. Values are mean \pm SEM. ${ }^{*} \mathrm{p}<0.05, * * \mathrm{p}<0.01, * * * \mathrm{p}<0.001$, and $* * * * \mathrm{p}<0.0001$ represent statistical significance between corresponding groups analyzed by One-way ANOVA. N=6-11/group.

Figure 2. Differential expression of genes (DEG) in the hearts of TAC/Benzene-exposed mice. A. The number of differentially expressed genes (DEG) are depicted by corresponding arrows. The visual representation of DEG for three treatments are presented as volcano plots (FDR $\leq 0.01)$. B. Heatmap of the top 15 up-regulated and 10 down-regulated (TAC/Benzene vs. TAC/Air) protein-encoding genes in the four experimental groups.

Figure 3. Pathway enrichment analysis of differentially expressed genes in the hearts of TAC/Benzene-exposed mice. A. Dot plot of enriched terms for TAC/Benzene vs TAC/Air DEG $($ FDR $\leq 0.01)$. IGF - Insulin-like Growth Factor, IGFBPs - Insulin-like Growth Factor Binding Proteins; B. The most upregulated and functionally important genes in TAC/Benzene vs TAC/Air groups. C. Gene-concept network depicting the linkage of genes and enriched biological pathways as a network.

Figure 4. Immune cells infiltration into the heart of TAC/Benzene-exposed mice. A. Heart sections were stained for S100A8 (green) and CD11b (pink), nuclei (blue); B. Co-staining of S100A8 positive cells with myeloperoxidase (MPO) positive cells. C. Quantitative analysis of 
S100A8-, CD11b-, and MPO-positive cells. D. Expression levels of adhesion genes in the hearts of exposed mice. Values are mean \pm SEM. ${ }^{*} \mathrm{p}<0.05,{ }^{* *} \mathrm{p}<0.01$ and ${ }^{* * *} \mathrm{p}<0.001$ represent statistical significance between corresponding groups analyzed by One-way ANOVA. N=6/group.

Figure 5. Benzene metabolites induce neutrophil adhesion to the cardiac microvascular endothelial cells. A. Transcription of P-selectin (Selp) in cardiac microvascular endothelial cells (CMVEC) treated with benzene metabolites hydroquinone (HQ; $5 \mu \mathrm{M}, 6 \mathrm{~h})$ and catechol $(5 \mu \mathrm{M}$, 24 h). B. HQ ( $5 \mu \mathrm{M}, 24 \mathrm{~h})$ - and catechol ( $5 \mu \mathrm{M}, 24 \mathrm{~h})$-induced upregulation of P-selectin protein in CMVEC. C. Adhesion of bone marrow-derived calcein-labeled murine neutrophils to CMVEC pretreated with HQ $(5 \mu \mathrm{M})$ and Catechol $(5 \mu \mathrm{M})$ for 24 hours. D. Inhibition of neutrophil adhesion to HQ $(5 \mu \mathrm{M}, 24 \mathrm{~h})$ - and catechol $(5 \mu \mathrm{M}, 24 \mathrm{~h})$-stimulated CMVEC by anti-P-selectin antibody. Values are mean \pm SEM. ${ }^{*} \mathrm{p}<0.05,{ }^{*} \mathrm{p}<0.01,{ }^{* * *} \mathrm{p}<0.001$, and $* * * * \mathrm{p}<0.0001$ between corresponding groups analyzed by One-way ANOVA.

7

(1)

(1)

1

2

3

4

5

6

7

8

9

0

1




\section{REFERENCES}

423 1. Collaborators, G.B.D.R.F. (2016) Global, regional, and national comparative risk assessment of 79 behavioural, environmental and occupational, and metabolic risks or clusters of risks, 19902015: a systematic analysis for the Global Burden of Disease Study 2015. Lancet. 388(10053): p. 1659-1724.

2. Clayton, C.A., E.D. Pellizzari, R.W. Whitmore, R.L. Perritt, and J.J. Quackenboss (1999) National Human Exposure Assessment Survey (NHEXAS): distributions and associations of lead, arsenic and volatile organic compounds in EPA region 5. J Expo Anal Environ Epidemiol. 9(5): p. 381-392.

3. Fraser, M.P., G.R. Cass, and B.R.T. Simoneit (1998) Gas-phase and particle-phase organic compounds emitted from motor vehicle traffic in a Los Angeles roadway tunnel. Environmental Science \& Technology. 32(14): p. 2051-2060.

4. Jacob, P., 3rd, A.H. Abu Raddaha, D. Dempsey, C. Havel, M. Peng, L. Yu, and N.L. Benowitz (2013) Comparison of nicotine and carcinogen exposure with water pipe and cigarette smoking. Cancer Epidemiol Biomarkers Prev. 22(5): p. 765-772.

5. Appel, B.R., G. Guirguis, I.S. Kim, O. Garbin, M. Fracchia, C.P. Flessel, K.W. Kizer, S.A. Book, and T.E. Warriner (1990) Benzene, benzo(a)pyrene, and lead in smoke from tobacco products other than cigarettes. Am J Public Health. 80(5): p. 560-564.

6. Smith, M.T. (2010) Advances in understanding benzene health effects and susceptibility. Annu Rev Public Health. 31: p. 133-148 132 p following 148.

7. Wong, O. and H. Fu (2005) Exposure to benzene and non-Hodgkin lymphoma, an epidemiologic overview and an ongoing case-control study in Shanghai. Chem Biol Interact. 153-154: p. 33-41.

8. Benjamin, E.J., M.J. Blaha, S.E. Chiuve, M. Cushman, S.R. Das, R. Deo, S.D. de Ferranti, J. Floyd, M. Fornage, C. Gillespie, C.R. Isasi, M.C. Jimenez, L.C. Jordan, S.E. Judd, D. Lackland, J.H. Lichtman, L. Lisabeth, S. Liu, C.T. Longenecker, R.H. Mackey, K. Matsushita, D. Mozaffarian, M.E. Mussolino, K. Nasir, R.W. Neumar, L. Palaniappan, D.K. Pandey, R.R. Thiagarajan, M.J. Reeves, M. Ritchey, C.J. Rodriguez, G.A. Roth, W.D. Rosamond, C. Sasson, A. Towfighi, C.W. Tsao, M.B. Turner, S.S. Virani, J.H. Voeks, J.Z. Willey, J.T. Wilkins, J.H. Wu, H.M. Alger, S.S. Wong, P. Muntner, C. American Heart Association Statistics, and S. Stroke Statistics (2017) Heart Disease and Stroke Statistics-2017 Update: A Report From the American Heart Association. Circulation. 135(10): p. e146-e603.

9. Ponikowski, P., S.D. Anker, K.F. AlHabib, M.R. Cowie, T.L. Force, S. Hu, T. Jaarsma, H. Krum, V. Rastogi, L.E. Rohde, U.C. Samal, H. Shimokawa, B. Budi Siswanto, K. Sliwa, and G. Filippatos (2014) Heart failure: preventing disease and death worldwide. ESC Heart Fail. 1(1): p. 4-25.

10. Lloyd-Jones, D.M., M.G. Larson, E.P. Leip, A. Beiser, R.B. D'Agostino, W.B. Kannel, J.M. Murabito, R.S. Vasan, E.J. Benjamin, D. Levy, and S. Framingham Heart (2002) Lifetime risk for developing congestive heart failure: the Framingham Heart Study. Circulation. 106(24): p. 3068-3072.

11. Kain, D., U. Amit, C. Yagil, N. Landa, N. Naftali-Shani, N. Molotski, V. Aviv, M.S. Feinberg, O. Goitein, T. Kushnir, E. Konen, F.H. Epstein, Y. Yagil, and J. Leor (2016) Macrophages dictate the progression and manifestation of hypertensive heart disease. Int J Cardiol. 203: p. 381-395.

12. Liao, X., Y. Shen, R. Zhang, K. Sugi, N.T. Vasudevan, M.A. Alaiti, D.R. Sweet, L. Zhou, Y. Qing, S.L. Gerson, C. Fu, A. Wynshaw-Boris, R. Hu, M.A. Schwartz, H. Fujioka, B. Richardson, M.J. Cameron, H. Hayashi, J.S. Stamler, and M.K. Jain (2018) Distinct roles of resident and nonresident macrophages in nonischemic cardiomyopathy. Proc Natl Acad Sci U S A. 115(20): p. E4661E4669.

13. Marinkovic, G., H. Grauen Larsen, T. Yndigegn, I.A. Szabo, R.G. Mares, L. de Camp, M. Weiland, L. Tomas, I. Goncalves, J. Nilsson, S. Jovinge, and A. Schiopu (2019) Inhibition of pro-inflammatory 
myeloid cell responses by short-term S100A9 blockade improves cardiac function after myocardial infarction. Eur Heart J. 40(32): p. 2713-2723.

14. Nahrendorf, M., F.K. Swirski, E. Aikawa, L. Stangenberg, T. Wurdinger, J.L. Figueiredo, P. Libby, R. Weissleder, and M.J. Pittet (2007) The healing myocardium sequentially mobilizes two monocyte subsets with divergent and complementary functions. J Exp Med. 204(12): p. 30373047.

15. Patel, B., M.A. Ismahil, T. Hamid, S.S. Bansal, and S.D. Prabhu (2017) Mononuclear Phagocytes Are Dispensable for Cardiac Remodeling in Established Pressure-Overload Heart Failure. PLoS One. 12(1): p. e0170781.

16. Sager, H.B., M. Hulsmans, K.J. Lavine, M.B. Moreira, T. Heidt, G. Courties, Y. Sun, Y. Iwamoto, B. Tricot, O.F. Khan, J.E. Dahlman, A. Borodovsky, K. Fitzgerald, D.G. Anderson, R. Weissleder, P. Libby, F.K. Swirski, and M. Nahrendorf (2016) Proliferation and Recruitment Contribute to Myocardial Macrophage Expansion in Chronic Heart Failure. Circ Res. 119(7): p. 853-864.

17. Weisheit, C., Y. Zhang, A. Faron, O. Kopke, G. Weisheit, A. Steinstrasser, S. Frede, R. Meyer, O. Boehm, A. Hoeft, C. Kurts, and G. Baumgarten (2014) Ly6C(low) and not Ly6C(high) macrophages accumulate first in the heart in a model of murine pressure-overload. PLoS One. 9(11): p. e112710.

18. Bajpai, G., C. Schneider, N. Wong, A. Bredemeyer, M. Hulsmans, M. Nahrendorf, S. Epelman, D. Kreisel, Y. Liu, A. Itoh, T.S. Shankar, C.H. Selzman, S.G. Drakos, and K.J. Lavine (2018) The human heart contains distinct macrophage subsets with divergent origins and functions. Nat Med. 24(8): p. 1234-1245.

19. Weinberger, T. and C. Schulz (2015) Myocardial infarction: a critical role of macrophages in cardiac remodeling. Front Physiol. 6: p. 107.

20. Halade, G.V., V. Kain, and K.A. Ingle (2018) Heart functional and structural compendium of cardiosplenic and cardiorenal networks in acute and chronic heart failure pathology. Am J Physiol Heart Circ Physiol. 314(2): p. H255-H267.

21. Martini, E., P. Kunderfranco, C. Peano, P. Carullo, M. Cremonesi, T. Schorn, R. Carriero, A. Termanini, F.S. Colombo, E. Jachetti, C. Panico, G. Faggian, A. Fumero, L. Torracca, M. Molgora, J. Cibella, C. Pagiatakis, J. Brummelman, G. Alvisi, E.M.C. Mazza, M.P. Colombo, E. Lugli, G. Condorelli, and M. Kallikourdis (2019) Single-Cell Sequencing of Mouse Heart Immune Infiltrate in Pressure Overload-Driven Heart Failure Reveals Extent of Immune Activation. Circulation. 140(25): p. 2089-2107.

22. Ma, Y., A. Yabluchanskiy, R.P. Iyer, P.L. Cannon, E.R. Flynn, M. Jung, J. Henry, C.A. Cates, K.Y. Deleon-Pennell, and M.L. Lindsey (2016) Temporal neutrophil polarization following myocardial infarction. Cardiovasc Res. 110(1): p. 51-61.

23. Horckmans, M., L. Ring, J. Duchene, D. Santovito, M.J. Schloss, M. Drechsler, C. Weber, O. Soehnlein, and S. Steffens (2017) Neutrophils orchestrate post-myocardial infarction healing by polarizing macrophages towards a reparative phenotype. Eur Heart J. 38(3): p. 187-197.

24. Lindsey, M.L., J.J. Saucerman, and K.Y. DeLeon-Pennell (2016) Knowledge gaps to understanding cardiac macrophage polarization following myocardial infarction. Biochim Biophys Acta. 1862(12): p. 2288-2292.

25. Ran, J., H. Qiu, S. Sun, A. Yang, and L. Tian (2018) Are ambient volatile organic compounds environmental stressors for heart failure? Environ Pollut. 242(Pt B): p. 1810-1816.

26. Bennett, O., N.B. Kandala, C. Ji, J. Linnane, and A. Clarke (2014) Spatial variation of heart failure and air pollution in Warwickshire, UK: an investigation of small scale variation at the ward-level. BMJ Open. 4(12): p. e006028.

27. Tsai, D.H., J.L. Wang, K.J. Chuang, and C.C. Chan (2010) Traffic-related air pollution and cardiovascular mortality in central Taiwan. Sci Total Environ. 408(8): p. 1818-1823. 
28. Villeneuve, P.J., M. Jerrett, J. Su, R.T. Burnett, H. Chen, J. Brook, A.J. Wheeler, S. Cakmak, and M.S. Goldberg (2013) A cohort study of intra-urban variations in volatile organic compounds and mortality, Toronto, Canada. Environ Pollut. 183: p. 30-39.

29. Baba, S.P., D. Zhang, M. Singh, S. Dassanayaka, Z. Xie, G. Jagatheesan, J. Zhao, V.K. Schmidtke, K.R. Brittian, M.L. Merchant, D.J. Conklin, S.P. Jones, and A. Bhatnagar (2018) Deficiency of aldose reductase exacerbates early pressure overload-induced cardiac dysfunction and autophagy in mice. J Mol Cell Cardiol. 118: p. 183-192.

30. Lang, A.L., L. Chen, G.D. Poff, W.X. Ding, R.A. Barnett, G.E. Arteel, and J.I. Beier (2018) Vinyl chloride dysregulates metabolic homeostasis and enhances diet-induced liver injury in mice. Hepatol Commun. 2(3): p. 270-284.

31. Dassanayaka, S., Y. Zheng, A.A. Gibb, T.D. Cummins, L.A. McNally, K.R. Brittian, G. Jagatheesan, T.N. Audam, B.W. Long, R.E. Brainard, S.P. Jones, and B.G. Hill (2018) Cardiac-specific overexpression of aldehyde dehydrogenase 2 exacerbates cardiac remodeling in response to pressure overload. Redox Biol. 17: p. 440-449.

32. An, O., K.T. Tan, Y. Li, J. Li, C.S. Wu, B. Zhang, L. Chen, and H. Yang (2020) CSI NGS Portal: An Online Platform for Automated NGS Data Analysis and Sharing. Int J Mol Sci. 21(11).

33. Watson, L.J., H.T. Facundo, G.A. Ngoh, M. Ameen, R.E. Brainard, K.M. Lemma, B.W. Long, S.D. Prabhu, Y.T. Xuan, and S.P. Jones (2010) O-linked beta-N-acetylglucosamine transferase is indispensable in the failing heart. Proc Natl Acad Sci U S A. 107(41): p. 17797-17802.

34. Watson, L.J., B.W. Long, A.M. DeMartino, K.R. Brittian, R.D. Readnower, R.E. Brainard, T.D. Cummins, L. Annamalai, B.G. Hill, and S.P. Jones (2014) Cardiomyocyte Ogt is essential for postnatal viability. Am J Physiol Heart Circ Physiol. 306(1): p. H142-153.

35. Swamydas, M., Y. Luo, M.E. Dorf, and M.S. Lionakis (2015) Isolation of Mouse Neutrophils. Curr Protoc Immunol. 110: p. 320 21-23 2015.

36. Wilhelmsen, K., K. Farrar, and J. Hellman (2013) Quantitative in vitro assay to measure neutrophil adhesion to activated primary human microvascular endothelial cells under static conditions. J Vis Exp. 2013/09/03(78): p. e50677.

37. Swirski, F.K. and M. Nahrendorf (2018) Cardioimmunology: the immune system in cardiac homeostasis and disease. Nat Rev Immunol. 18(12): p. 733-744.

38. Silvestre-Roig, C., Q. Braster, A. Ortega-Gomez, and O. Soehnlein (2020) Neutrophils as regulators of cardiovascular inflammation. Nat Rev Cardiol. 17(6): p. 327-340.

39. Wang, Y., S. Sano, K. Oshima, M. Sano, Y. Watanabe, Y. Katanasaka, Y. Yura, C. Jung, A. Anzai, F.K. Swirski, N. Gokce, and K. Walsh (2019) Wnt5a-Mediated Neutrophil Recruitment Has an Obligatory Role in Pressure Overload-Induced Cardiac Dysfunction. Circulation. 140(6): p. 487499.

40. Frangogiannis, N.G. (2017) The extracellular matrix in myocardial injury, repair, and remodeling. J Clin Invest. 127(5): p. 1600-1612.

41. Hutchinson, K.R., J.A. Stewart, Jr., and P.A. Lucchesi (2010) Extracellular matrix remodeling during the progression of volume overload-induced heart failure. J Mol Cell Cardiol. 48(3): p. 564-569.

42. Salvador, A.M., T. Nevers, F. Velazquez, M. Aronovitz, B. Wang, A. Abadia Molina, I.Z. Jaffe, R.H. Karas, R.M. Blanton, and P. Alcaide (2016) Intercellular Adhesion Molecule 1 Regulates Left Ventricular Leukocyte Infiltration, Cardiac Remodeling, and Function in Pressure OverloadInduced Heart Failure. J Am Heart Assoc. 5(3): p. e003126.

43. Bliksoen, M., L.H. Mariero, M.K. Torp, A. Baysa, K. Ytrehus, F. Haugen, I. Seljeflot, J. Vaage, G. Valen, and K.O. Stenslokken (2016) Extracellular mtDNA activates NF-kappaB via toll-like receptor 9 and induces cell death in cardiomyocytes. Basic Res Cardiol. 111(4): p. 42. 
44. Lipps, C., J.H. Nguyen, L. Pyttel, T.L.t. Lynch, C. Liebetrau, G. Aleshcheva, S. Voss, O. Dorr, H.M. Nef, H. Mollmann, C.W. Hamm, S. Sadayappan, and C. Troidl (2016) N-terminal fragment of cardiac myosin binding protein-C triggers pro-inflammatory responses in vitro. J Mol Cell Cardiol. 99: p. 47-56.

45. Krysko, D.V., P. Agostinis, O. Krysko, A.D. Garg, C. Bachert, B.N. Lambrecht, and P. Vandenabeele (2011) Emerging role of damage-associated molecular patterns derived from mitochondria in inflammation. Trends Immunol. 32(4): p. 157-164.

46. Shioi, T., A. Matsumori, Y. Kihara, M. Inoko, K. Ono, Y. Iwanaga, T. Yamada, A. Iwasaki, K. Matsushima, and S. Sasayama (1997) Increased expression of interleukin-1 beta and monocyte chemotactic and activating factor/monocyte chemoattractant protein-1 in the hypertrophied and failing heart with pressure overload. Circ Res. 81(5): p. 664-671.

47. Patel, B., S.S. Bansal, M.A. Ismahil, T. Hamid, G. Rokosh, M. Mack, and S.D. Prabhu (2018) CCR2(+) Monocyte-Derived Infiltrating Macrophages Are Required for Adverse Cardiac Remodeling During Pressure Overload. JACC Basic Trans/ Sci. 3(2): p. 230-244.

48. Vandal, K., P. Rouleau, A. Boivin, C. Ryckman, M. Talbot, and P.A. Tessier (2003) Blockade of S100A8 and S100A9 suppresses neutrophil migration in response to lipopolysaccharide. $J$ Immunol. 171(5): p. 2602-2609.

49. Ryckman, C., K. Vandal, P. Rouleau, M. Talbot, and P.A. Tessier (2003) Proinflammatory activities of S100: proteins S100A8, S100A9, and S100A8/A9 induce neutrophil chemotaxis and adhesion. J Immunol. 170(6): p. 3233-3242.

50. Morrow, D.A., Y. Wang, K. Croce, M. Sakuma, M.S. Sabatine, H. Gao, A.D. Pradhan, A.M. Healy, J. Buros, C.H. McCabe, P. Libby, C.P. Cannon, E. Braunwald, and D.I. Simon (2008) Myeloid-related protein 8/14 and the risk of cardiovascular death or myocardial infarction after an acute coronary syndrome in the Pravastatin or Atorvastatin Evaluation and Infection Therapy: Thrombolysis in Myocardial Infarction (PROVE IT-TIMI 22) trial. Am Heart J. 155(1): p. 49-55.

51. Healy, A.M., M.D. Pickard, A.D. Pradhan, Y. Wang, Z. Chen, K. Croce, M. Sakuma, C. Shi, A.C. Zago, J. Garasic, A.I. Damokosh, T.L. Dowie, L. Poisson, J. Lillie, P. Libby, P.M. Ridker, and D.I. Simon (2006) Platelet expression profiling and clinical validation of myeloid-related protein-14 as a novel determinant of cardiovascular events. Circulation. 113(19): p. 2278-2284.

52. Ichikawa, M., R. Williams, L. Wang, T. Vogl, and G. Srikrishna (2011) S100A8/A9 activate key genes and pathways in colon tumor progression. Mol Cancer Res. 9(2): p. 133-148.

53. Buonafine, M., E. Martinez-Martinez, C. Amador, B. Gravez, J. Ibarrola, A. Fernandez-Celis, S. El Moghrabi, P. Rossignol, N. Lopez-Andres, and F. Jaisser (2018) Neutrophil Gelatinase-Associated Lipocalin from immune cells is mandatory for aldosterone-induced cardiac remodeling and inflammation. J Mol Cell Cardiol. 115: p. 32-38.

54. Marques, F.Z., P.R. Prestes, S.G. Byars, S.C. Ritchie, P. Wurtz, S.K. Patel, S.A. Booth, I. Rana, Y. Minoda, S.P. Berzins, C.L. Curl, J.R. Bell, B. Wai, P.M. Srivastava, A.J. Kangas, P. Soininen, S. Ruohonen, M. Kahonen, T. Lehtimaki, E. Raitoharju, A. Havulinna, M. Perola, O. Raitakari, V. Salomaa, M. Ala-Korpela, J. Kettunen, M. McGlynn, J. Kelly, M.E. Wlodek, P.A. Lewandowski, L.M. Delbridge, L.M. Burrell, M. Inouye, S.B. Harrap, and F.J. Charchar (2017) Experimental and Human Evidence for Lipocalin-2 (Neutrophil Gelatinase-Associated Lipocalin [NGAL]) in the Development of Cardiac Hypertrophy and heart failure. J Am Heart Assoc. 6(6).

55. Yndestad, A., T. Ueland, E. Oie, G. Florholmen, B. Halvorsen, H. Attramadal, S. Simonsen, S.S. Froland, L. Gullestad, G. Christensen, J.K. Damas, and P. Aukrust (2004) Elevated levels of activin A in heart failure: potential role in myocardial remodeling. Circulation. 109(11): p. 1379-1385.

56. Yan, L., N. Borregaard, L. Kjeldsen, and M.A. Moses (2001) The high molecular weight urinary matrix metalloproteinase (MMP) activity is a complex of gelatinase B/MMP-9 and neutrophil 
gelatinase-associated lipocalin (NGAL). Modulation of MMP-9 activity by NGAL. J Biol Chem. 276(40): p. 37258-37265.

57. Nuntagowat, C., K. Leelawat, and R. Tohtong (2010) NGAL knockdown by siRNA in human cholangiocarcinoma cells suppressed invasion by reducing NGAL/MMP-9 complex formation. Clin Exp Metastasis. 27(5): p. 295-305.

58. Boyd, J.H., B. Kan, H. Roberts, Y. Wang, and K.R. Walley (2008) S100A8 and S100A9 mediate endotoxin-induced cardiomyocyte dysfunction via the receptor for advanced glycation end products. Circ Res. 102(10): p. 1239-1246.

59. Tang, W.H., M.L. Brennan, K. Philip, W. Tong, S. Mann, F. Van Lente, and S.L. Hazen (2006) Plasma myeloperoxidase levels in patients with chronic heart failure. Am J Cardiol. 98(6): p. 796799.

60. Ali, M., B. Pulli, G. Courties, B. Tricot, M. Sebas, Y. Iwamoto, I. Hilgendorf, S. Schob, A. Dong, W. Zheng, A. Skoura, A. Kalgukar, C. Cortes, R. Ruggeri, F.K. Swirski, M. Nahrendorf, L. Buckbinder, and J.W. Chen (2016) Myeloperoxidase Inhibition Improves Ventricular Function and Remodeling After Experimental Myocardial Infarction. JACC Basic Trans/ Sci. 1(7): p. 633-643.

61. Griffith, J.W., C.L. Sokol, and A.D. Luster (2014) Chemokines and chemokine receptors: positioning cells for host defense and immunity. Annu Rev Immunol. 32: p. 659-702.

62. Miyake, M., S. Goodison, V. Urquidi, E. Gomes Giacoia, and C.J. Rosser (2013) Expression of CXCL1 in human endothelial cells induces angiogenesis through the CXCR2 receptor and the ERK1/2 and EGF pathways. Lab Invest. 93(7): p. 768-778.

63. Scapini, P., M. Morini, C. Tecchio, S. Minghelli, E. Di Carlo, E. Tanghetti, A. Albini, C. Lowell, G. Berton, D.M. Noonan, and M.A. Cassatella (2004) CXCL1/macrophage inflammatory protein-2induced angiogenesis in vivo is mediated by neutrophil-derived vascular endothelial growth factor-A. J Immunol. 172(8): p. 5034-5040.

64. Wang, L., Y.L. Zhang, Q.Y. Lin, Y. Liu, X.M. Guan, X.L. Ma, H.J. Cao, Y. Liu, J. Bai, Y.L. Xia, J. Du, and H.H. Li (2018) CXCL1-CXCR2 axis mediates angiotensin II-induced cardiac hypertrophy and remodelling through regulation of monocyte infiltration. Eur Heart J. 39(20): p. 1818-1831.

65. Gillis, B., I.M. Gavin, Z. Arbieva, S.T. King, S. Jayaraman, and B.S. Prabhakar (2007) Identification of human cell responses to benzene and benzene metabolites. Genomics. 90(3): p. 324-333.

66. Bironaite, D., D. Siegel, J.L. Moran, B.B. Weksler, and D. Ross (2004) Stimulation of endothelial IL-8 (elL-8) production and apoptosis by phenolic metabolites of benzene in HL-60 cells and human bone marrow endothelial cells. Chem Biol Interact. 149(2-3): p. 177-188.

67. Gerszten, R.E., E.A. Garcia-Zepeda, Y.C. Lim, M. Yoshida, H.A. Ding, M.A. Gimbrone, Jr., A.D. Luster, F.W. Luscinskas, and A. Rosenzweig (1999) MCP-1 and IL-8 trigger firm adhesion of monocytes to vascular endothelium under flow conditions. Nature. 398(6729): p. 718-723.

68. Gomez-Pastor, R., E.T. Burchfiel, and D.J. Thiele (2018) Regulation of heat shock transcription factors and their roles in physiology and disease. Nat Rev Mol Cell Biol. 19(1): p. 4-19.

69. Sakamoto, M., T. Minamino, H. Toko, Y. Kayama, Y. Zou, M. Sano, E. Takaki, T. Aoyagi, K. Tojo, N. Tajima, A. Nakai, H. Aburatani, and I. Komuro (2006) Upregulation of heat shock transcription factor 1 plays a critical role in adaptive cardiac hypertrophy. Circ Res. 99(12): p. 1411-1418.

70. Zhou, N., Y. Ye, X. Wang, B. Ma, J. Wu, L. Li, L. Wang, D.W. Wang, and Y. Zou (2017) Heat shock transcription factor 1 protects against pressure overload-induced cardiac fibrosis via Smad3. J Mol Med (Berl). 95(4): p. 445-460.

71. Du, P., Y. Chang, F. Dai, C. Wei, Q. Zhang, and J. Li (2018) Role of heat shock transcription factor 1 (HSF1)-upregulated macrophage in ameliorating pressure overload-induced heart failure in mice. Gene. 667: p. 10-17.

72. Zou, Y., J. Li, H. Ma, H. Jiang, J. Yuan, H. Gong, Y. Liang, A. Guan, J. Wu, L. Li, N. Zhou, Y. Niu, A. Sun, A. Nakai, P. Wang, H. Takano, I. Komuro, and J. Ge (2011) Heat shock transcription factor 1 
protects heart after pressure overload through promoting myocardial angiogenesis in male mice. J Mol Cell Cardiol. 51(5): p. 821-829.

660

73. Uchiyama, T., H. Atsuta, T. Utsugi, M. Oguri, A. Hasegawa, T. Nakamura, A. Nakai, M. Nakata, I. Maruyama, H. Tomura, F. Okajima, S. Tomono, S. Kawazu, R. Nagai, and M. Kurabayashi (2007) HSF1 and constitutively active HSF1 improve vascular endothelial function (heat shock proteins improve vascular endothelial function). Atherosclerosis. 190(2): p. 321-329.

664

74. Takii, R., S. Inouye, M. Fujimoto, T. Nakamura, T. Shinkawa, R. Prakasam, K. Tan, N. Hayashida, H. Ichikawa, T. Hai, and A. Nakai (2010) Heat shock transcription factor 1 inhibits expression of IL-6 through activating transcription factor 3. J Immunol. 184(2): p. 1041-1048. 

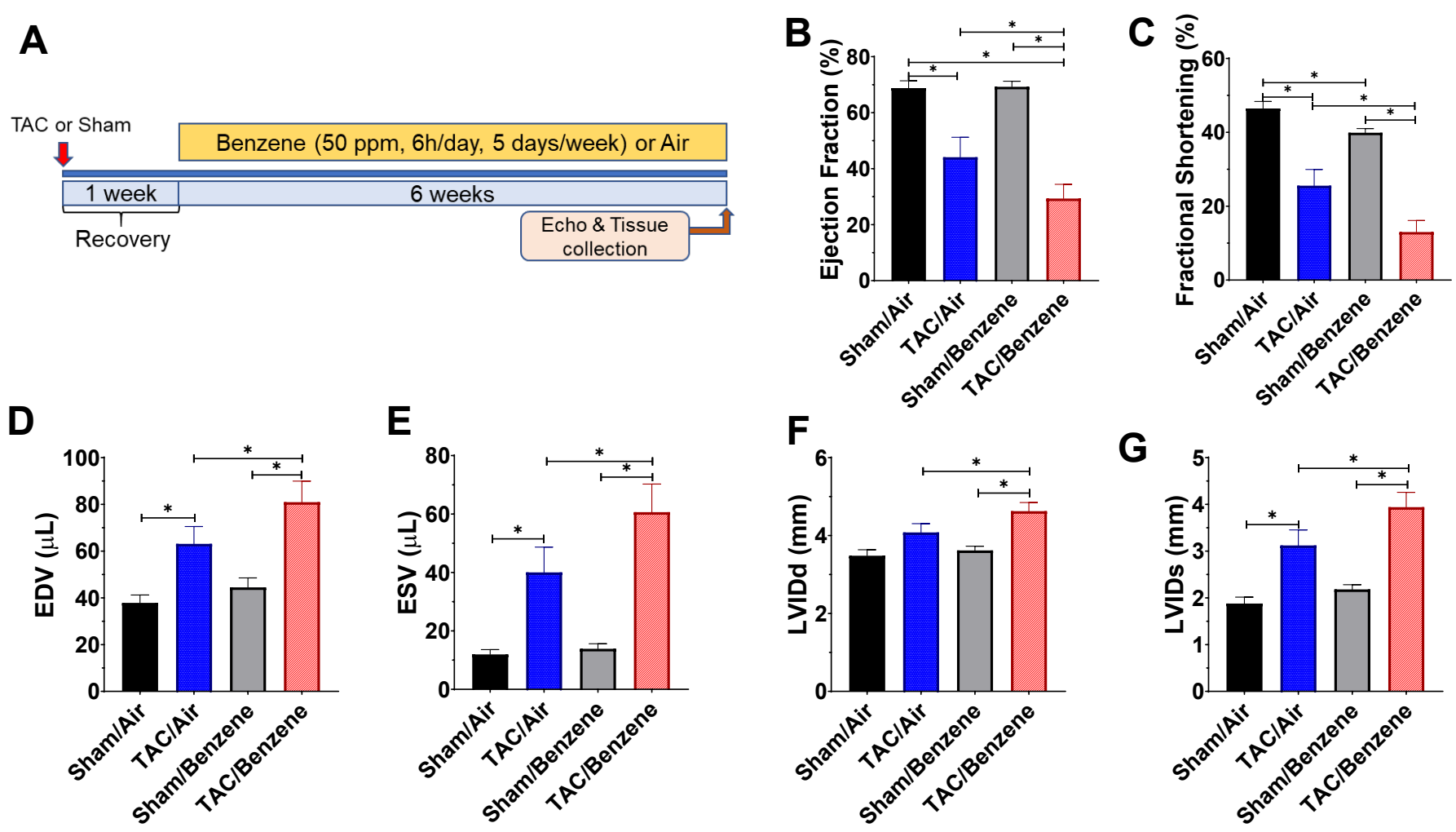

H
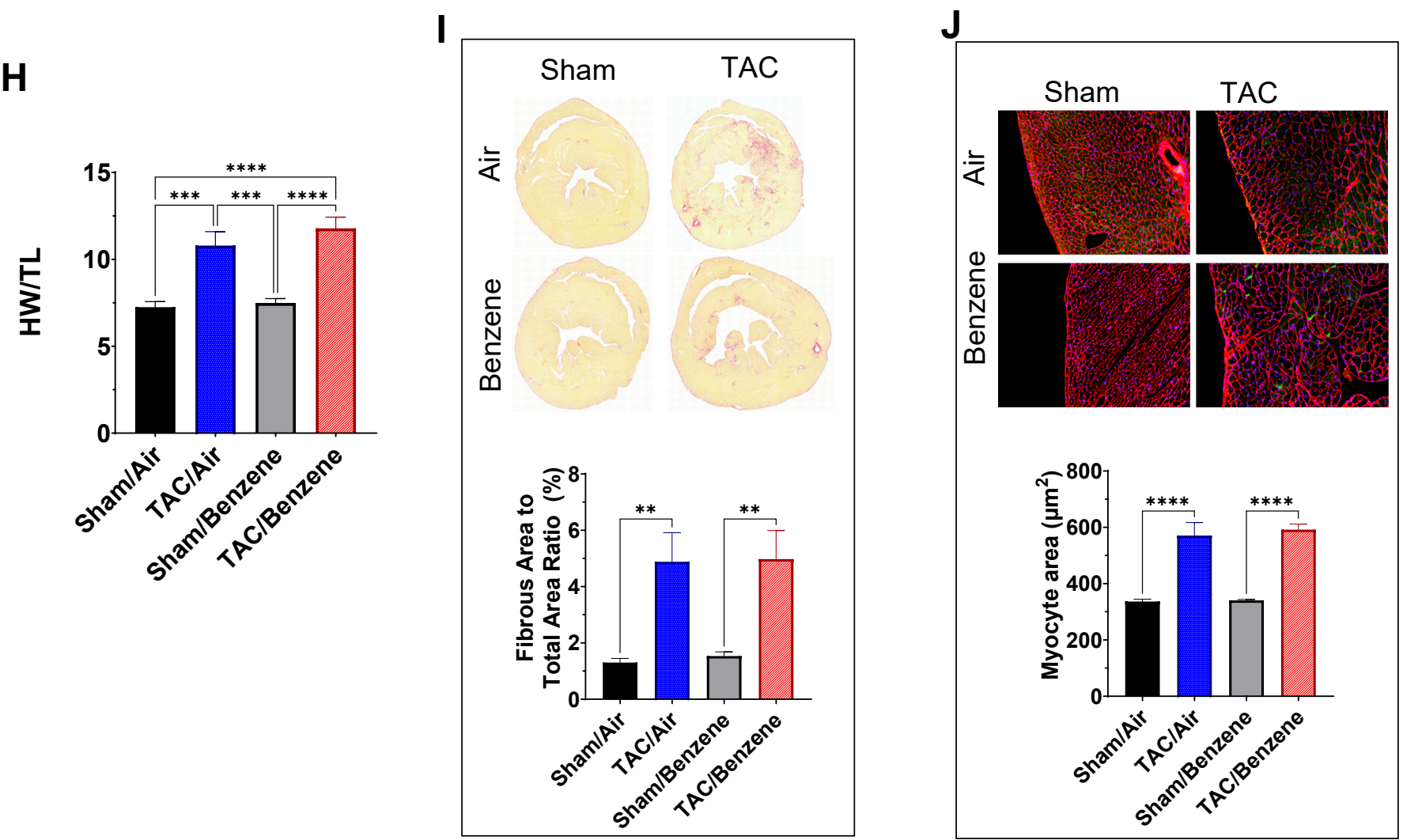

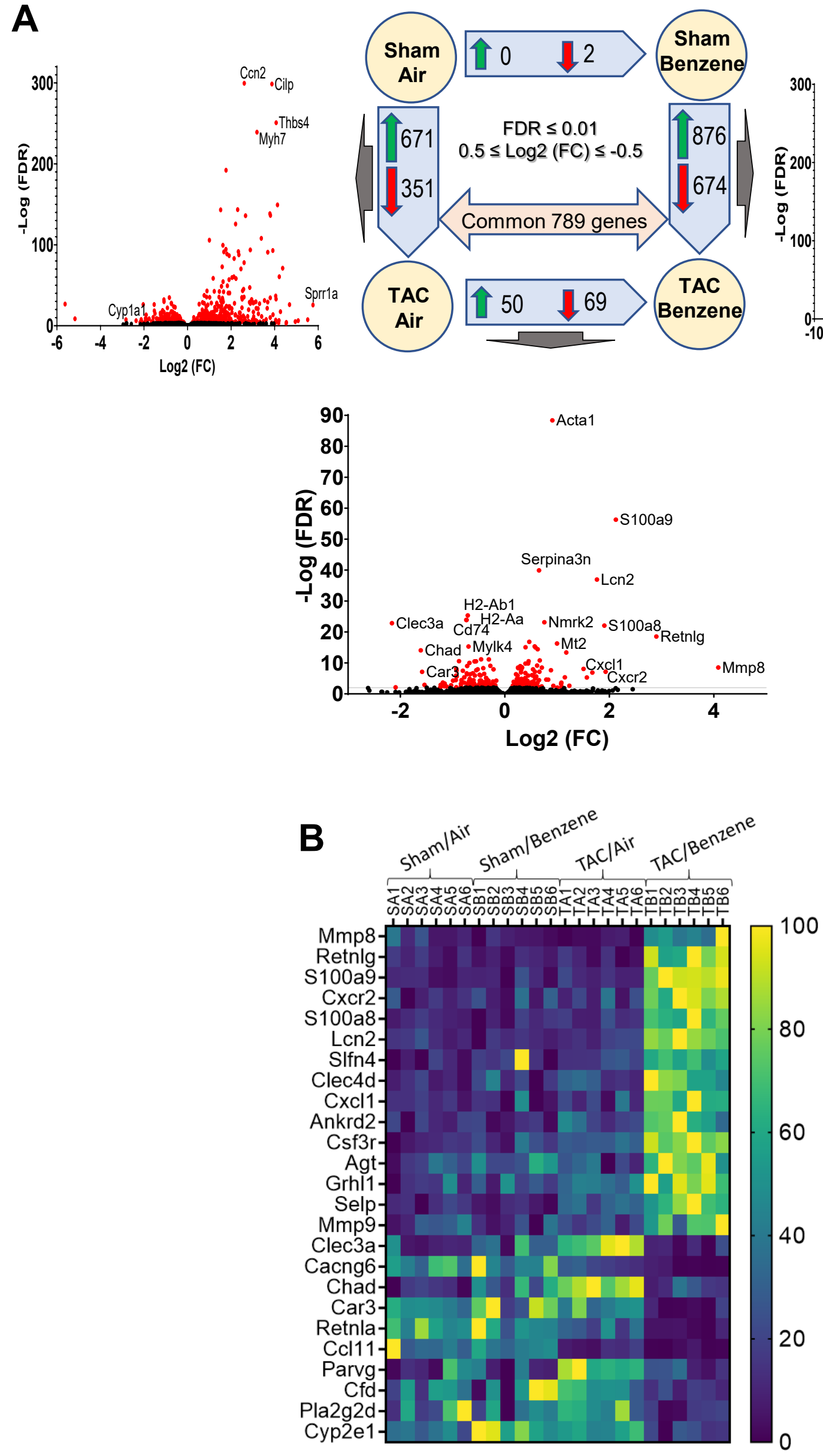
A

Neutrophil degranulation

Signaling by Interleukins

Extracellular matrix organization

Interleukin-4 \& -13 signaling

Regulation of IGF transport and uptake by IGFBPs

Platelet degranulation

Response to elevated platelet cytosolic $\mathrm{Ca}^{2+}$

Post-translational protein phosphorylation

IL-10 signaling

HSF1-dependent transactivation
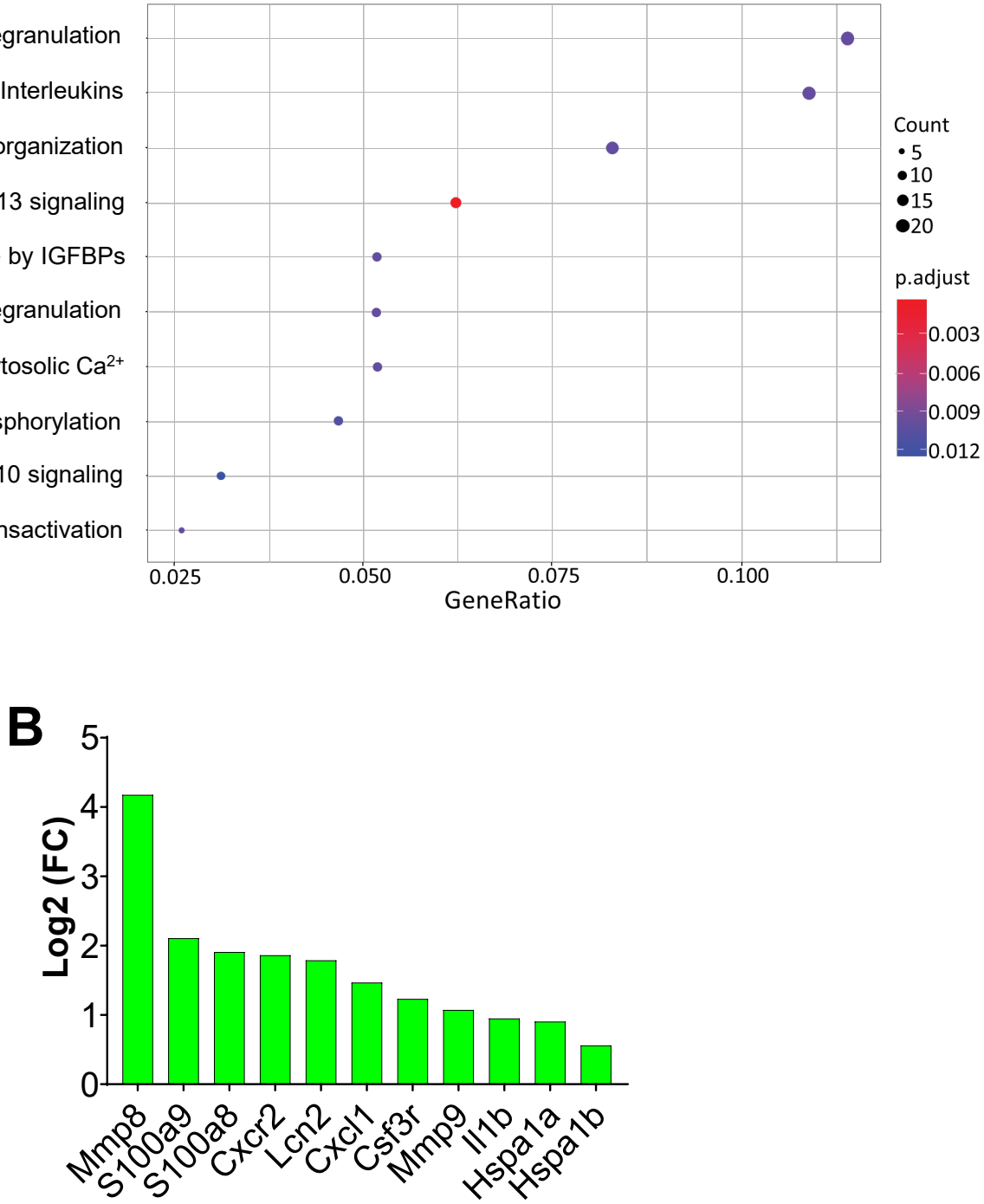

C

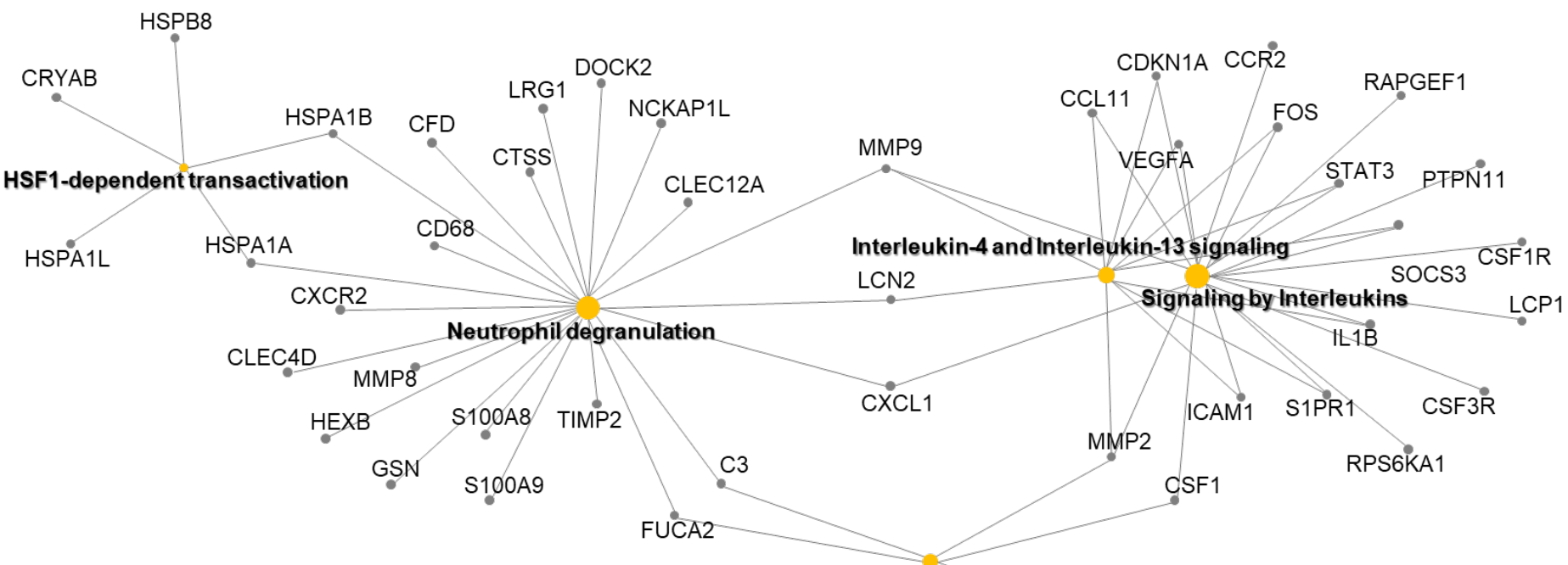

Regulation of IGF transport and uptake by IGFBPs 


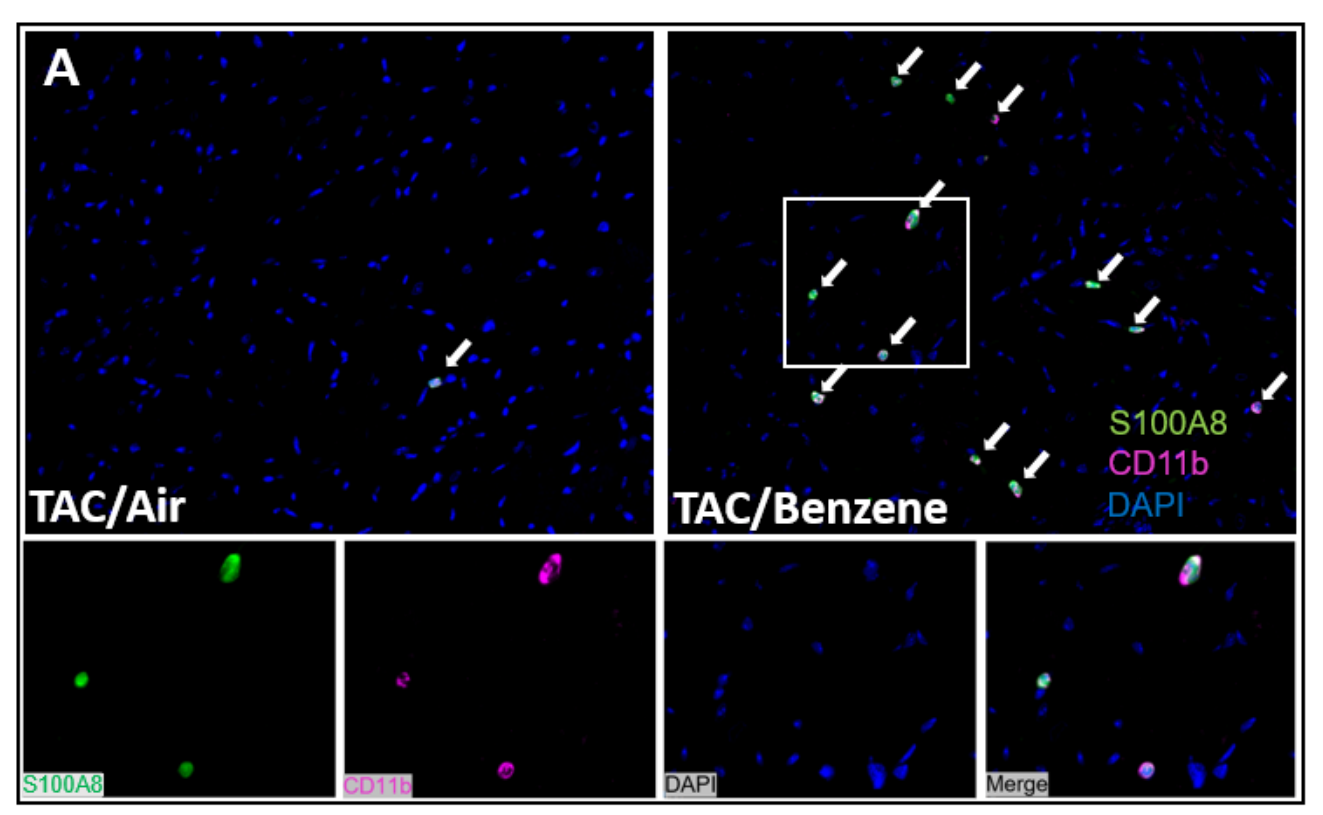

Figure 4

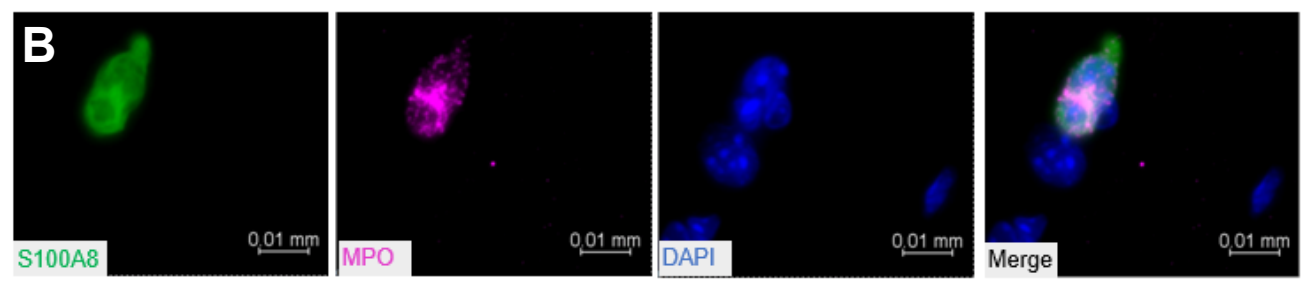

C
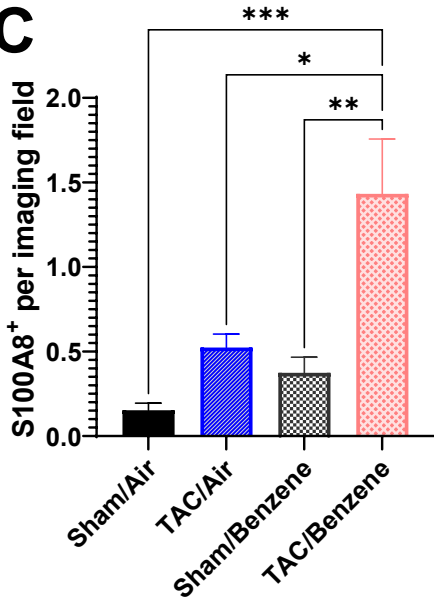
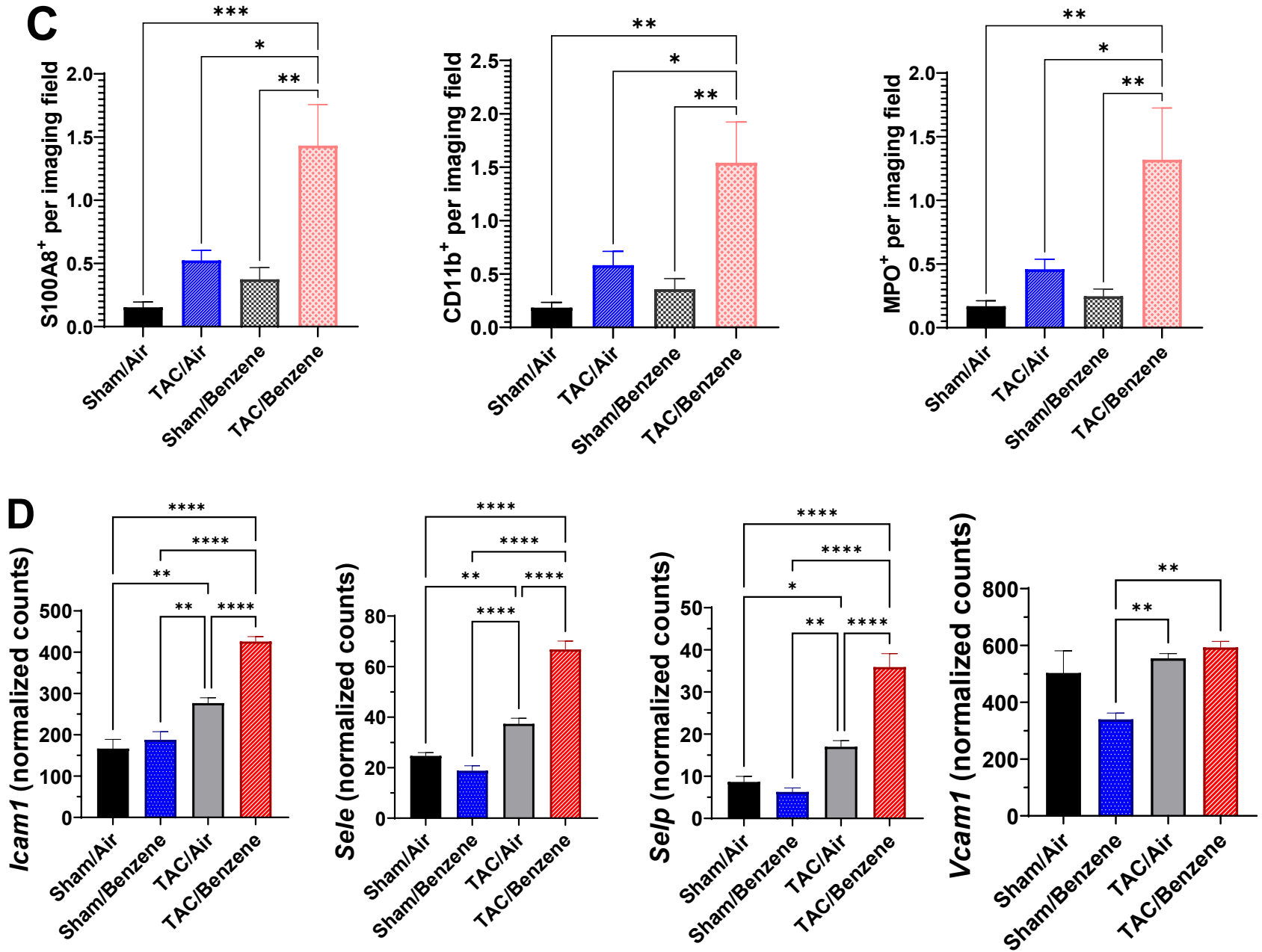
Figure 5
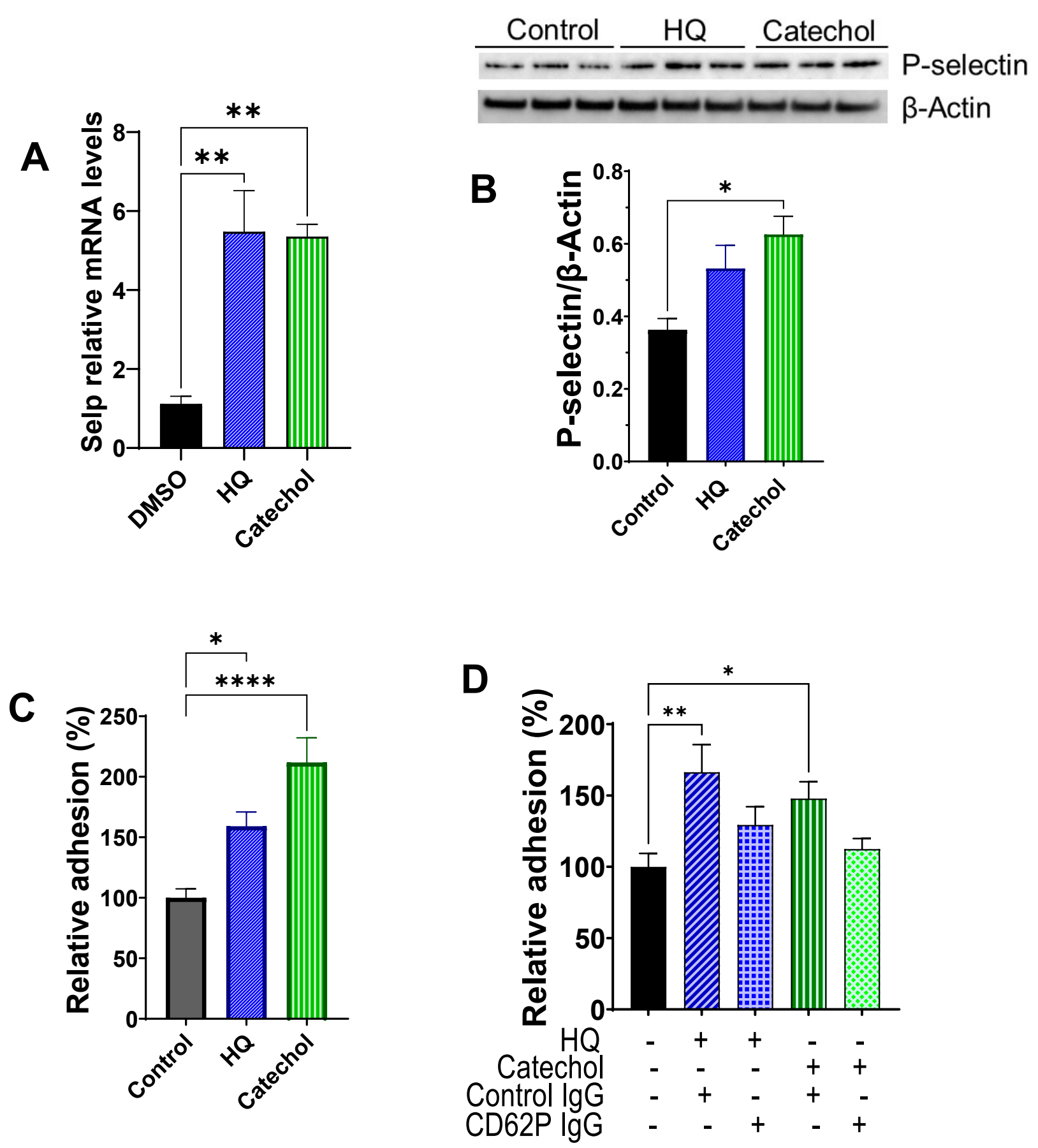
Supplementary Table 1. Echocardiographic parameters of transverse aortic constriction or sham operated mice followed by benzene or air exposure for 6 weeks.

\begin{tabular}{|c|c|c|c|c|}
\hline Parameters & Sham/Air & Sham/Benzene & TAC/Air & TAC/Benzene \\
\hline IVRT $(\mathrm{ms})$ & $11.1 \pm 0.6$ & $12.6 \pm 0.7$ & $16.2 \pm 2.0$ & $17.8 \pm 2.3^{*}$ \\
\hline LVAWd $(\mathrm{mm})$ & $1.3 \pm 0.1$ & $1.2 \pm 0.03$ & $1.4 \pm 0.04^{\S}$ & $1.4 \pm 0.07$ \\
\hline LVAWs $(\mathrm{mm})$ & $1.9 \pm 0.07$ & $1.8 \pm 0.04$ & $1.8 \pm 0.06$ & $1.7 \pm 0.09$ \\
\hline LVPWd $(\mathrm{mm})$ & $1.1 \pm 0.04$ & $1.0 \pm 0.05$ & $1.3 \pm 0.1^{\S}$ & $1.2 \pm 0.06$ \\
\hline LVPWs $(\mathrm{mm})$ & $1.8 \pm 0.06$ & $1.5 \pm 0.06$ & $1.6 \pm 0.09$ & $1.5 \pm 0.09^{*}$ \\
\hline HR $(\mathrm{bpm})$ & $534 \pm 11$ & $514 \pm 12$ & $523 \pm 9$ & $549 \pm 9$ \\
\hline Endo CO $(\mathrm{mL} / \mathrm{min})$ & $13.7 \pm 1.01$ & $15.6 \pm 1.21$ & $12.1 \pm 0.98$ & $11.2 \pm 1.03^{\S}$ \\
\hline SV $(\mu \mathrm{L})$ & $25.9 \pm 2.3$ & $30.6 \pm 2.7$ & $23.1 \pm 1.9$ & $20.3 \pm 1.7^{\S}$ \\
\hline
\end{tabular}

Values are mean \pm SEM. $\mathrm{N}=10-12$ per group. ${ }^{*} \mathrm{p} \leq 0.05$ vs Sham/Air, ${ }^{\S} \mathrm{p} \leq 0.05$ vs Sham/Benzene. Statistical analyses were performed by One-way ANOVA. 


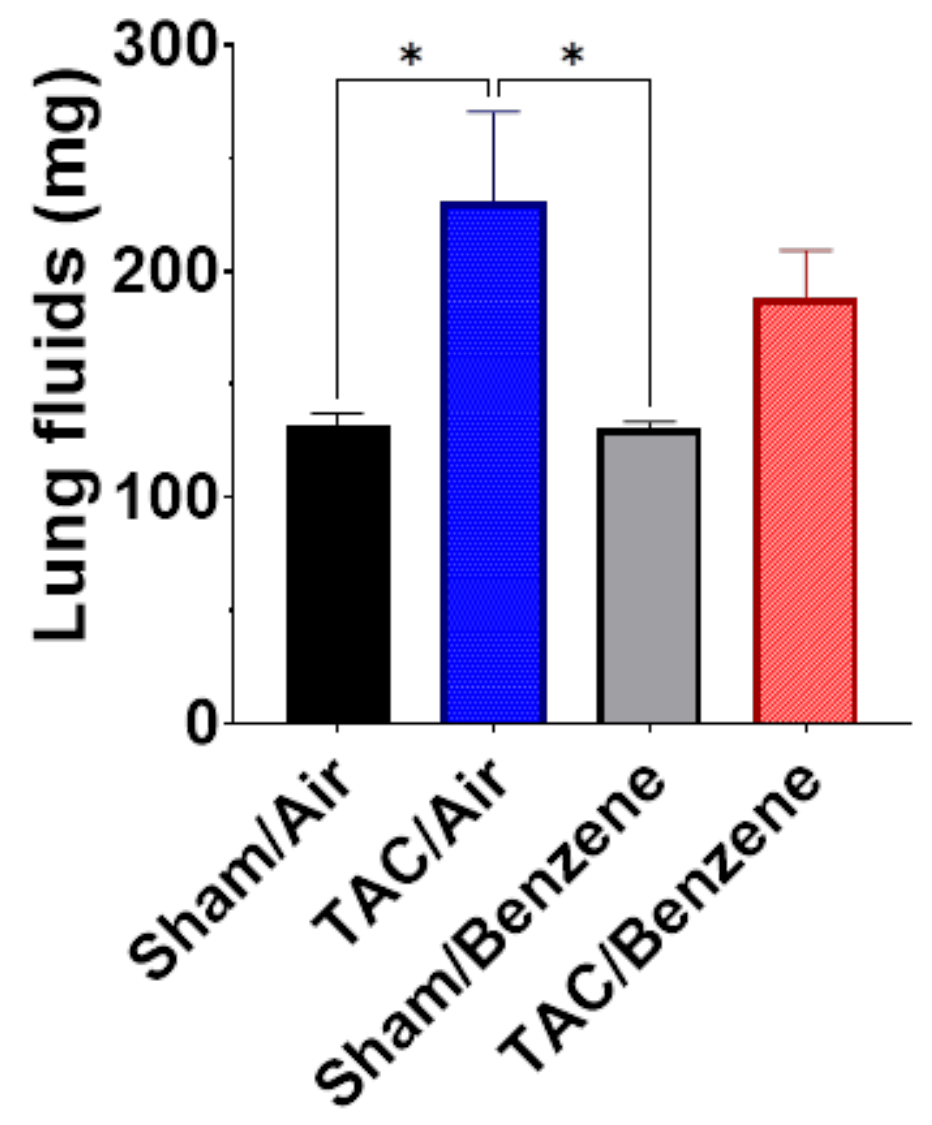

Supplementary Figure 1. Pulmonary edema in transverse aortic constriction or Sham operated mice exposed to benzene or air for 6 weeks. Accumulation of the fluid in the lung was measured by subtracting the dry weight of the tissue from the wet weight. Values are mean $\pm \mathrm{SEM}, \mathrm{N}=10$ 12 per group. ${ }^{*} \mathrm{p}<0.05$ between corresponding groups. Statistical analyses were performed by Oneway ANOVA. 

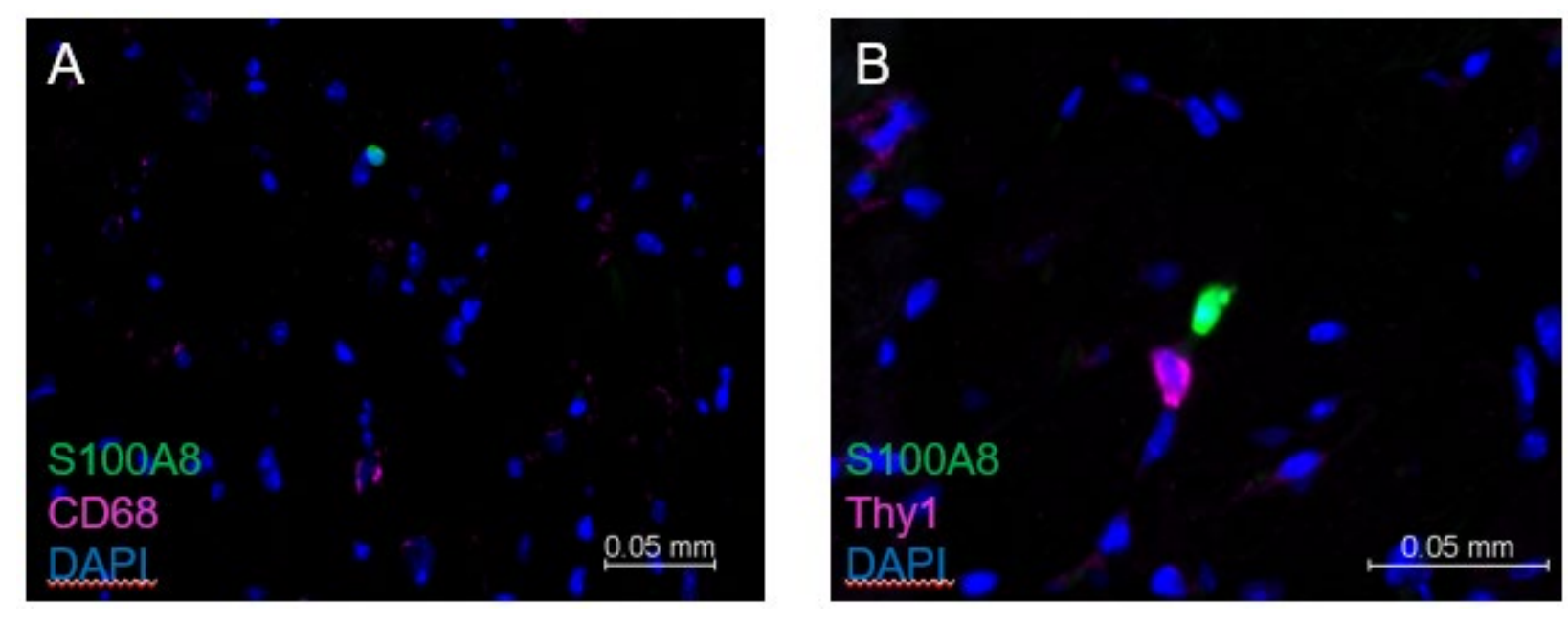

Supplementary Figure 2. Staining of immune cells in the hearts of TAC/Benzene-exposed mice. Hearts from the TAC/Benzene mice were stained with granulocyte marker S100A8, macrophage marker CD68, or fibroblast marker Thy1. Nuclei were stained with DAPI (blue). 


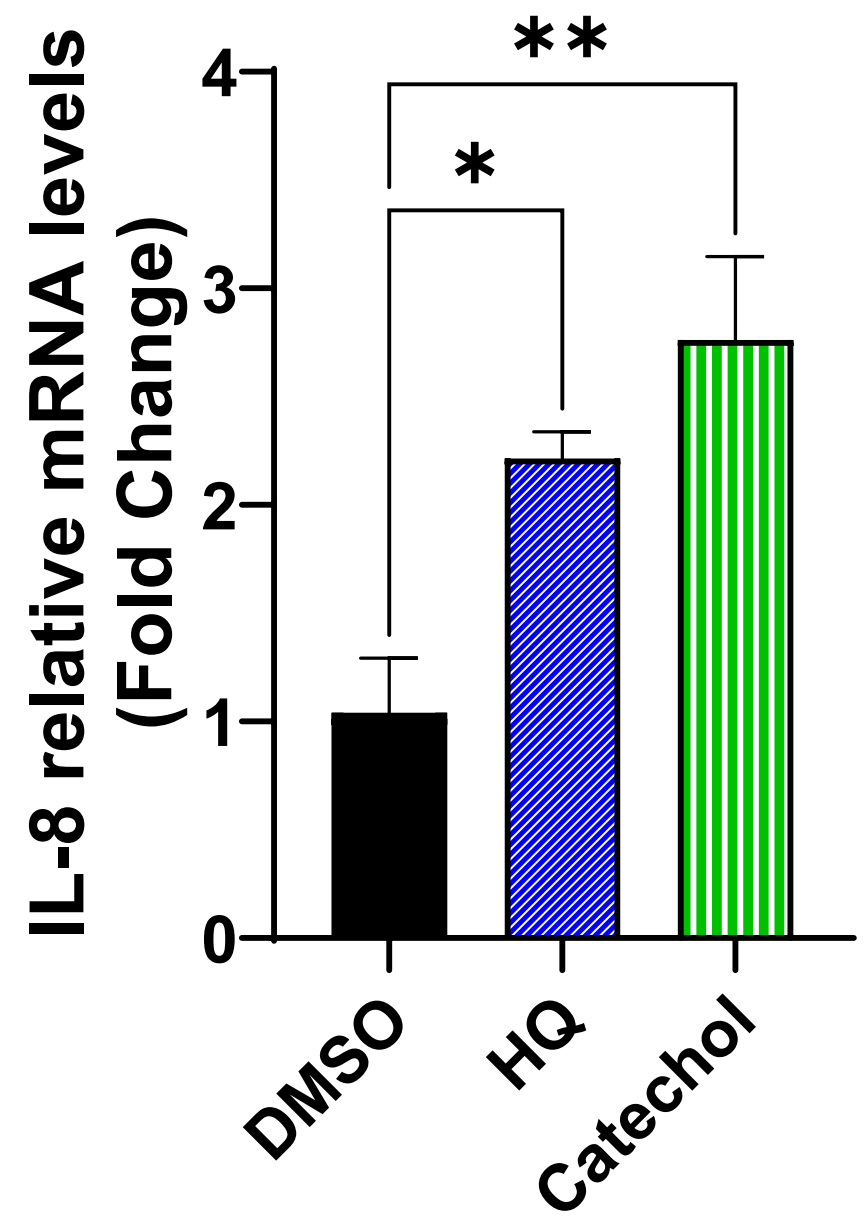

Supplementary Figure 3. Expression of chemokine IL8 in hydroquinone (HQ, $5 \mu \mathrm{M} / 24 \mathrm{~h}$ ) and catechol cardiac $(5 \mu \mathrm{M} / 24 \mathrm{~h})$-treated cardiac microvascular endothelial cells. Values are mean \pm SEM, $\mathrm{N}=3$ per group. ${ }^{*} \mathrm{p}<0.05,{ }^{*} \mathrm{p}<0.01$ between corresponding groups. Statistical analyses were performed by One-way ANOVA. 